Article

\title{
Assessment of Optional Sediment Transport Functions via the Complex Watershed Simulation Model SWAT
}

\author{
Haw Yen ${ }^{1, *}$, Shenglan Lu ${ }^{2}$, Qingyu Feng ${ }^{3}$, Ruoyu Wang ${ }^{4}$, Jungang Gao ${ }^{1}$, Dawn Michelle Brady ${ }^{5}$, \\ Amirreza Sharifi ${ }^{6}$, Jungkyu Ahn ${ }^{7}$, Shien-Tsung Chen ${ }^{8}$, Jaehak Jeong ${ }^{1}$, Michael James White ${ }^{9}$ \\ and Jeffrey George Arnold ${ }^{9}$ \\ 1 Blackland Research and Extension Center, Texas A\&M University, 720 East Blackland Road, \\ Temple, TX 76502, USA; jgao@brc.tamus.edu (J.G.); jjeong@brc.tamus.edu (J.J.) \\ 2 Department of Bioscience, Aarhus University, Vejlsøvej 27, 8600 Silkeborg, Denmark; sl@dmu.dk \\ 3 Department of Agricultural and Biological Engineering, Purdue University, Hovde Hall, 610 Purdue Mall, \\ West Lafayette, IN 47907, USA; feng37@purdue.edu \\ 4 Integrated Environmental Modeling Branch, United States Environmental Protection Agency, \\ Raleigh, NC 27695, USA; wang1283@purdue.edu \\ 5 Aqua-Aerobic Systems, Inc., 6306 N Alpine Rd, Loves Park, IL 61111, USA; dawn.brady7@gmail.com \\ 6 Department of Environmental Science and Technology, University of Maryland, \\ College Park, MD 20742, USA; Amirreza.Sharifi@ARS.USDA.GOV \\ 7 Department of Civil and Environmental Engineering, Incheon National University, 119 Academy-ro, \\ Yeonsu-gu, Incheon 22012, Korea; ahnjk@inu.ac.kr \\ 8 Department of Water Resources Engineering and Conservation, Feng Chia University, \\ Taichung City 40724, Taiwan; stchen@fcu.edu.tw \\ 9 Grassland, Soil \& Water Research Laboratory, United States Department of Agriculture Agricultural \\ Research Service, 808 East Blackland Road, Temple, TX 76502, USA; Mike.White@ARS.USDA.GOV (M.J.W.); \\ Jeff.Arnold@ARS.USDA.GOV (J.G.A.) \\ * Correspondence: haw.yen@gmail.com or hyen@brc.tamus.edu
}

Academic Editor: Marco Franchini

Received: 3 October 2016; Accepted: 18 January 2017; Published: 28 January 2017

\begin{abstract}
The Soil and Water Assessment Tool 2012 (SWAT2012) offers four sediment routing methods as optional alternatives to the default simplified Bagnold method. Previous studies compared only one of these alternative sediment routing methods with the default method. The proposed study evaluated the impacts of all four alternative sediment transport methods on sediment predictions: the modified Bagnold equation, the Kodoatie equation, the Molinas and Wu equation, and the Yang equation. The Arroyo Colorado Watershed, Texas, USA, was first calibrated for daily flow. The sediment parameters were then calibrated to monthly sediment loads, using each of the four sediment routing equations. An automatic calibration tool-Integrated Parameter Estimation and Uncertainty Analysis Tool (IPEAT)—was used to fit model parameters. The four sediment routing equations yielded substantially different sediment sources and sinks. The Yang equation performed best, followed by Kodoatie, Bagnold, and Molinas and Wu equations, according to greater model goodness-of-fit (represented by higher Nash-Sutcliffe Efficiency coefficient and percent bias closer to 0 ) as well as lower model uncertainty (represented by inclusion of observed data within 95\% confidence interval). Since the default method (Bagnold) does not guarantee the best results, modelers should carefully evaluate the selection of alternative methods before conducting relevant studies or engineering projects.
\end{abstract}

Keywords: sediment transport; model calibration; SWAT; uncertainty analysis; IPEAT 


\section{Introduction}

The semi-distributed watershed simulation model, Soil and Water Assessment Tool (SWAT) [1] has been applied worldwide to identify critical source areas of water quality impairments and evaluate potential solutions through land use change and water resource planning and management [2-9]. Various SWAT applications have been conducted to explore sediment loading from watersheds [10-13]. Most SWAT sediment studies have focused on sediment transport in surface and bank erosion [13-15], while comparatively few studies have taken into account sediment transport within streams [16,17]. In addition, excess sediment loads can cause silting problems and damage aquatic habitats [18]. In recent years, research related to sediment yield and transportation has increased considerably [19]. Challenges such as erosion of fertile topsoil, blocking stream channels, and filling reservoirs have the potential to impact agricultural productivity [20].

In SWAT version 2012 (SWAT2012), the simulation of sediment transport in channels was updated by including four equations for sediment routing by particle size along with the simplified Bagnold equation [21] incorporated in SWAT since the 2005 version [22]. The alternative methods are (1) modified Bagnold equation [21]; (2) Kodoatie equation [23]; (3) Molinas and Wu equation [24]; and (4) Yang equation [25]. The four sediment transport equations were developed based on different theories and bed materials. The Bagnold equation was modified by Williams [26] to calculate the maximum sediment transport capacity via the velocity function of peak stream. The Kodoatie equation calculates the maximum transport capacity with flow depths, stream geometry, and bed materials, beside flow velocity. The Molinas and Wu equation calculates the maximum transport capacity with universal stream power, which is related to flow depth and particle fall velocity. The Yang equation calculates the maximum transport capacity with unit stream power and includes mean and critical velocity, shear velocity, material fall velocity, kinematic viscosity, critical stream power for incipient motion, and particle size.

Each of the four alternative sediment transport functions in SWAT calculates sediment transport mechanisms differently [22]. SWAT applies the principle of sediment transport capacity to further route sediment processes through main reaches or channels. Sediment deposition or streambed degradation is determined based on the current sediment concentration in the channel system and the estimated sediment transport capacity. Only the modified Bagnold equation will be examined in this study. Comparisons between the simplified and modified version, which both have the same equation for maximum transport capacity, were previously conducted to evaluate the effect on sediment predictions $[19,27]$. The major difference between the two equations is that the modified Bagnold equation is able to simulate the mechanism of bank erosion. In addition, the modified Bagnold equation may provide better predictions of low sediment concentrations than the simplified version (which is also the default sediment transport function) $[19,27]$. Selection of alternative methods could be justified based on the river bed materials (particle types), specified ranges of particle size, physical assumptions of mathematical equations and the associated impacts on model calibration and predictions.

The four alternative sediment transport routing methods (modified Bagnold, Kodoatie, Molinas and $\mathrm{Wu}$, and Yang) have not previously been compared or investigated with respect to maximum sediment transport capacity in SWAT2012. The goal of this study is to evaluate the potential influence of the four alternative sediment transport methods on sediment loads and concentrations using a SWAT model developed for the Arroyo Colorado watershed (ACW), in Southern Texas, USA. Specifically, the following objectives were pursued: (i) to assess the performance of each respective sediment transport routing method on predicting flow and sediment in SWAT; and (ii) to quantify and to evaluate the corresponding predictive uncertainty associated with these methods. 


\section{Materials and Methods}

\subsection{The SWAT Model}

The SWAT model is a spatially distributed, semi-physically-based watershed simulation model developed and maintained by the Agricultural Research Service, United States Department of Agriculture to evaluate the impact of land management and climate change on flow and water quality processes [2]. Relevant functions of SWAT include weather components, hydrology, land use, crop growth, sediment transport routines, fate of nutrients, and conservation practices, which are capable of evaluating various hydrological, hydrochemical, and biophysical processes [3,6,28]. SWAT is a complex watershed simulation model conducted on daily time steps. In addition, large-scale, long-term simulations/predictions are available in alternative time scales (e.g., daily, monthly and annual). Implementations of SWAT can be found in various subjects including sediments transport, nutrients processes, and pesticide applications in varying watersheds of the world [29-31]. Modifications of SWAT and comparisons among alternative routing methods are available in literature [32-36].

\subsection{Study Area}

The Arroyo Colorado watershed (ACW) is a part of the Nueces-Rio Grande Coastal Basin located in Southern Texas, USA (sharing its border with Mexico, see Figure 1). The Arroyo Colorado River (ACR) in ACW is a branch of the Rio Grande River and the drainage area of $1692 \mathrm{~km}^{2}$ within three counties (Cameron, Hidalgo, and Willacy Counties) [37]. In general, the ACW is comprehensively developed in terms of agricultural activities and urbanization. Specifically, more anthropogenic development can be found in the central and the western parts of the ACW (e.g., cities such as Donna, Harlingen, McAllen, Mercedes, Mission, Pharr, San Benito, and Weslaco) [37].

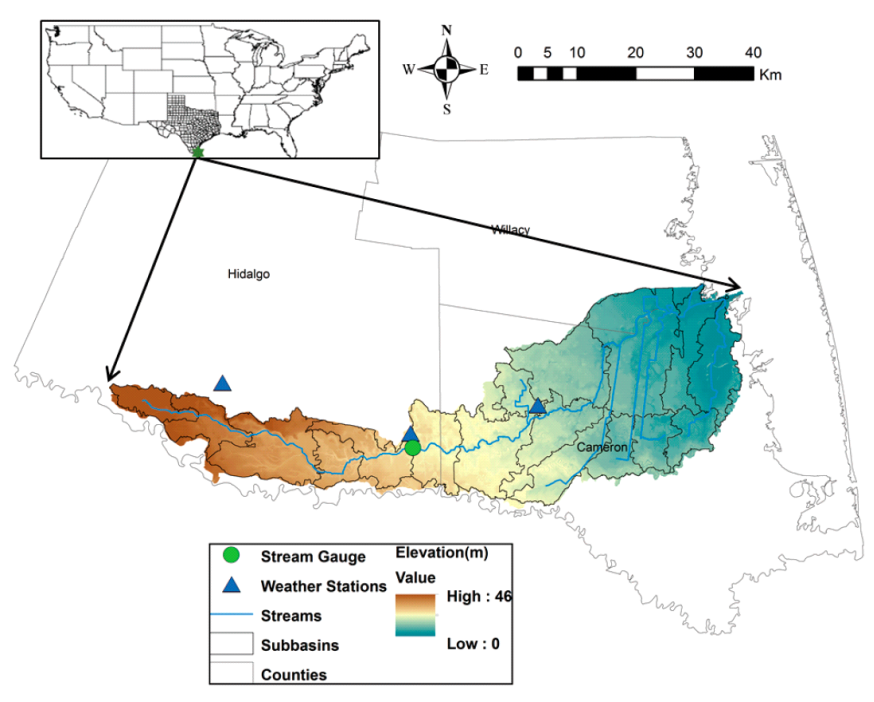

Figure 1. Location of the Arroyo Colorado Watershed [38].

As shown in Figure 2, agriculture (54\%), rangeland (18.5\%) and urban areas $(12.5 \%)$ are the three major land use categories in the ACW, whereas the commonly cultivated crops are cane, cotton, citrus, sorghum, and vegetables. The predominant soils in the ACW are sandy loams (0.06-2 mm), clay loams $(0.002-0.006 \mathrm{~mm})$, and clays $(<0.002 \mathrm{~mm})$, whereas the depth of soil layers is ranging from $1600 \mathrm{~mm}$ to $2000 \mathrm{~mm}$. In SWAT, temperature and precipitation are the two major climate model inputs. The average annual temperature in the ACW is $28.9^{\circ} \mathrm{C}$ in July and $14.5^{\circ} \mathrm{C}$ in January which can also be considered as the reference data for summer and winter. The average annual precipitation ranges from $530 \mathrm{~mm}$ to $680 \mathrm{~mm}$ which can also be categorized as the semi-arid climate region. More details of the ACW can also be found in [37]. 


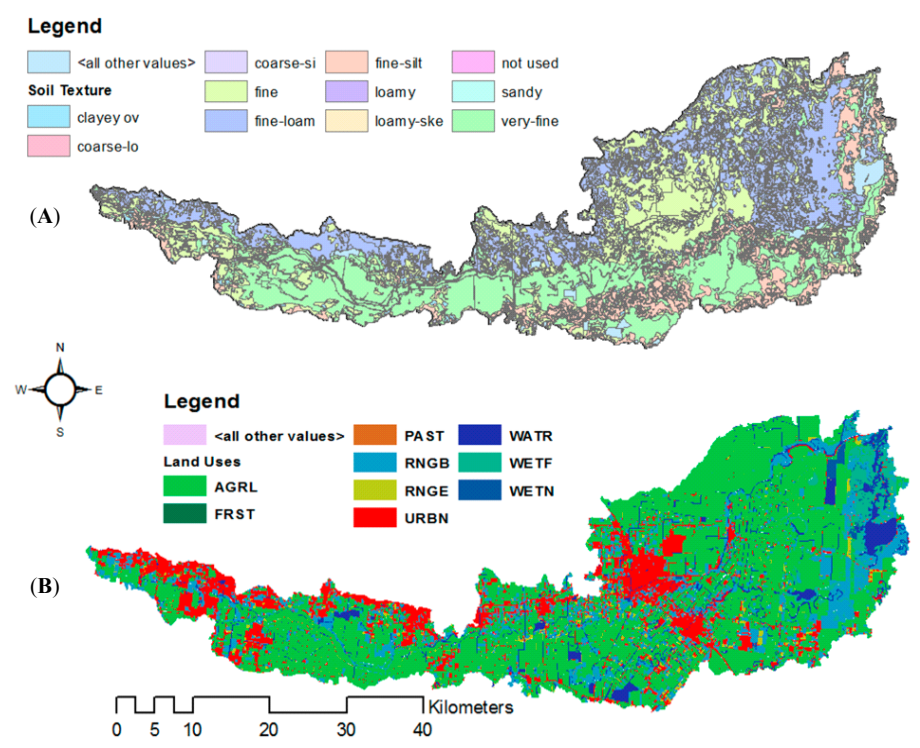

Figure 2. Demonstration of the (A) land use; and (B) soil types, of the Arroyo Colorado Watershed (AGRL: Agricultural Land-Row Crops; FRST: Mixed Forest; PAST: Pasture; RNGB: Range-Brush; RNGE: Range-Grass; URBN: Urban; WATR: Water; WETF; Wetland-Forest; and WETN: Wetland-NonForest).

\subsection{Sources of Input Data}

Meteorological records (e.g., precipitation, temperature), anthropogenic activities (e.g., agricultural operation, urban usage), and measured hydrological data were integrated by the ArcSWAT system (ArcSWAT 2012.10.18, Texas A\&M University, College Station, Texas, USA) which is a platform that incorporates the SWAT model and GIS (Geographic Information System) with a user-friendly interface. A Digital Elevation Model (DEM) with a spatial resolution of $30 \mathrm{~m} \times 30 \mathrm{~m}$ downloaded from the National Elevation Dataset of the U.S. Geological Survey (USGS) [39], was used to generate sub-basins of the SWAT model in the ACW [40]. Additional information of SWAT included a land use map representing land cover conditions for 2004-2007 and the soil map from the Soil Survey Geographic Database (SSURGO), USDA-NRCS (United States Department of Agriculture-Natural Resources Conservation Service). In the SWAT model, the watershed was divided into 17 sub-basins comprising 475 Hydrological Response Units (HRUs) further subdivided by land use, soil and slope combinations. Crops and management practices including tillage practices, irrigation management, and nutrient application rate and timing were obtained by local agencies including Texas Commission of Environmental Quality (TCEQ), Texas AgriLife Research, Texas State Soil and Water Conservation Board (TSSWCB), and Natural Resources Conservation Service (NRCS). In addition, best management practices involving land leveling, irrigation management, nutrient management methods in the period of 1999-2006 were provide by TSSWCB.

Daily weather data (minimum-maximum air temperature and precipitation during the period 2000-2005) were collected for model inputs from three stations: COOPID 413943 near Harlingen; COOPID 415836 near Mercedes; and COOPID 419588 near Weslaco (managed by Texas State Climatologist Office located at Texas A\&M University at College Station). The stream flow data of a gauge station (near Llano Grande at FM (Farm-to-Market Road) 1015 south of Weslaco) was provided by International Boundary and Water Commission. In addition, there was a total of 21 permitted point sources with discharges in the ACW, including 16 municipal districts with discharge permit limits ranging from 0.4 to 10 million gallons per day, three industrial areas, and two shrimp farms with infrequent discharge [41].

The watershed modeling work conducted in this study was designed to enhance the living quality of local colonia residents [37]. However, one of the challenging issues was the lack of observation data especially for sediment loads (substantially restricted by available funding supported). It was stated 
in Harmel et al. [42] and Yen et al. [43] that model performance (in terms of statistics) of watershed modeling could be substantially affected by the quality of measurement data. For sediment loadings alone, measurement uncertainty may reach up to $117 \%$. Therefore, the selection of alternative functions should be even more carefully examined while an insufficient amount of data was acquired. We tried to make the best use of the available measurement data in the sense of fulfilling a complete watershed modeling project. In this study, suspended sediment (SS) was evaluated by water quality data from limited grab samples (7-8 times per year). LOAD ESTimator (LOADEST) is a software package developed by USGS that can automatically conduct regression analysis to generate estimated water quality data. Available observation records are used to fill gaps at time steps with missing data. In this case, LOADEST was used to convert the grab-samples into time series loads with monthly mean values within the $95 \%$ confidence interval [44], as observed data to calibrate SWAT. For more information on the input and sampling data of the ACW, see the research by Seo et al. [38].

\subsection{Sediment Transport Methods in SWAT}

SWAT2012 offers four alternative sediment routing methods to the model's standard method. All sediment routing equations share the same in-stream sediment routing (sediment transport capacity is routed in main reaches/channels) but calculate the maximum sediment transport capacity (maximum concentration of transportable sediment) differently. A brief introduction of the four methods is described as follows, and further details can be found in the SWAT User's Manual [22].

\subsubsection{Modified Bagnold Equation}

The Bagnold equation is the default choice for calculating maximum transport capacity from a reach segment in SWAT. This method determines the maximum transport capacity as a function of channel slope and velocity. The equation was developed by Williams [26] based on stream power as defined by Bagnold [21]. The maximum transport capacity from a reach segment is calculated by Equation (1).

$$
\operatorname{conc}_{s e d, c h, m x}=c_{s p} \cdot v_{c h, p k} S P E X P
$$

where, $c o n c_{s e d, c h, m x}$ is the sediment concentration (maximum) transported by water $\left(\operatorname{ton} / \mathrm{m}^{3}\right) ; c_{s p}$ (SPCON) is the user defined sediment coefficient; $v_{c h, p k}$ is the peak channel velocity $(\mathrm{m} / \mathrm{s}) ;$ and SPEXP is the user defined coefficient in the exponential term [1]. In SWAT2012, extension of the Bagnold stream power function served as a separate modeling option from the default Bagnold method. The modified Bagnold equation includes consideration of the shear stress deployed by the water on the river bank as well as the stream bed that dislodges sediment particles based on the concept of critical shear stress [45].

\subsubsection{Kodoatie Equation}

The Kodoatie equation is suitable for streams that have bed materials of sizes ranging from silt to gravel. The equation was modified by Kodoatie [23] based on the equation developed by Posada [46] via the nonlinear optimization approach to categorize data from the field in various riverbed sediment sizes. The maximum transport capacity is represented as Equation (2).

$$
\operatorname{conc}_{s e d, c h, m x}=\left(\frac{a \cdot v_{c h} b \cdot y^{c} \cdot S^{d}}{Q_{i n}}\right) \cdot\left(\frac{W+W_{b m}}{2}\right)
$$

where, $v_{c h}$ is the mean flow velocity $(\mathrm{m} / \mathrm{s}) ; y$ is the mean flow depth $(\mathrm{m}) ; S$ is the energy slope $(\mathrm{m} / \mathrm{m})$ (in SWAT, the value of $S$ is projected the same as bed slope in all cases); regression coefficients for the Kodoatie equation are defined as $a, b, c$ and $d$ in categorizing four different bed materials; $Q_{i n}$ is the daily water volume that enters each sub-basin $\left(\mathrm{m}^{3}\right) ; W$ is the channel width at water surface $(\mathrm{m})$; and $W_{b m}$ is the bottom channel width (m). 


\subsubsection{Molinas and $\mathrm{Wu}$ Equation}

By the application of universal stream power, the Molinas and Wu equation was designed for simulating large sand-bed rivers. The equation was developed by Molinas and $\mathrm{Wu}[24]$ using universal stream power to calculate the maximum transport capacity.

$$
C_{w}=M \psi^{N}
$$

where, $C_{w}$ is the sediment concentration by weight $(\mathrm{mg} / \mathrm{L}) ; \psi$ is the universal stream power; $M$ and $N$ are user defined coefficients. The equation was calibrated using large river basins as test cases and the following equation is derived:

$$
C_{w}=\frac{1430 \cdot(0.86+\sqrt{\psi}) \cdot \psi^{1.5}}{0.016+\psi} \cdot 10^{-6}
$$

The universal stream power $\psi$, can be expressed as:

$$
\psi=\frac{v_{c h}{ }^{3}}{\left(S_{g}-1\right) \cdot g \cdot \operatorname{depth} \cdot \omega_{50} \cdot\left[\log _{10}\left(\frac{\text { depth }}{D_{50}}\right)\right]^{2}}
$$

where, $S_{g}$ is the solid relative density $\left(2.65 \mathrm{~g} / \mathrm{cm}^{3}\right.$ for this study); $g$ is the gravity acceleration $\left(9.81 \mathrm{~m} / \mathrm{s}^{2}\right)$; depth is the flow depth $(\mathrm{m}) ; \omega_{50}$ is the fall velocity $(\mathrm{m} / \mathrm{s})$ for median size particles; $D_{50}$ is the median of sediment size (mm).

\subsubsection{Yang Sand and Gravel Equation}

The method was developed mainly for simulation of sand and gravel materials. Yang [47] calculated the total sand transport rate as excess unit stream power (the unit stream power is defined as the time rate of potential energy dissipation per unit weight of water), which is a product of velocity and slope. Yang [48] extended the unit stream power equation for sand to gravel loading. Equations for sand and gravel were separately developed based on regression of critical unit stream power, fall velocity, kinematic viscosity, sediment size, shear velocity, and unit stream power. The equations for sand (median sizes $D_{50}$, less than $2 \mathrm{~mm}$ ) are as follows:

$$
\begin{gathered}
\log C_{w, p p m}=5.435-0.286 \log \frac{\omega_{50} D_{50}}{v}-0.457 \log \frac{V_{*}}{\omega_{50}} \\
+\left(1.799-0.409 \log \frac{\omega_{50} D_{50}}{v}-0.314 \log \frac{V_{*}}{\omega_{50}}\right) \log \left(\frac{v_{c h} S}{\omega_{50}}-\frac{V_{c h} S}{\omega_{50}}\right)
\end{gathered}
$$

and for gravel ( $D_{50}$ between $2 \mathrm{~mm}$ and $10 \mathrm{~mm}$ ) are:

$$
\begin{gathered}
\log C_{w, p p m}=6.681-0.633 \log \frac{\omega_{50} D_{50}}{v}-4.816 \log \frac{V_{*}}{\omega_{50}} \\
+\left(2.784-0.305 \log \frac{\omega_{50} D_{50}}{v}-0.282 \log \frac{V_{*}}{\omega_{50}}\right) \log \left(\frac{v_{c h} S}{\omega_{50}}-\frac{V_{c h} S}{\omega_{50}}\right)
\end{gathered}
$$

where $C_{w, p p m}$ is the sediment concentration $(\mathrm{mg} / \mathrm{L}) ; v$ is the kinematic viscosity $\left(\mathrm{m}^{2} / \mathrm{s}\right) ; V_{*}$ is the shear velocity $(\mathrm{m} / \mathrm{s}) ; V_{c h}$ is the critical velocity $(\mathrm{m} / \mathrm{s}) ;$ and $v_{c h}$ is the mean channel velocity $(\mathrm{m} / \mathrm{s})$. The results of sediment concentration in $\mathrm{mg} / \mathrm{L}$ are divided by $10^{6}$ to convert to concentration by weight, and then the conversion equation for Molinas and $\mathrm{Wu}$ is used to convert to maximum bed load concentration in metric ton $/ \mathrm{m}^{3}$.

\subsection{Model Calibration and Validation}

In this study, calibration consisted of testing each of the four scenarios in SWAT whereas alternative sediment routing equations were tested. The scenario name and equation tested in each scenario were (i) Scenario 01: Modified Bagnold equation; (ii) Scenario 02: Kodoatie model; (iii) Scenario 03: Molinas 
and Wu model; and (iv) Scenario 04: Yang sand and gravel model. Calibration of the SWAT model for the ACW was conducted from 2002 to 2003 (warmup years from 2000 to 2001) and the validation period was from 2004 to 2005. Daily streamflow and monthly sediment were calibrated via the Integrated Parameter Estimation and Uncertainty Analysis Tool (IPEAT) [49]. IPEAT is a framework for both auto-calibration and uncertainty analysis which adopts Dynamically Dimensioned Search (DDS) as the major parameter estimation technique [50] (however, DDS can be replaced by other methods under the IPEAT framework). In addition, IPEAT has been demonstrated to have superior performance (e.g., convergence speed and the ability to find better solutions) over other commonly implemented auto-calibration techniques such as Shuffle Complex Evolution (SCE-UA) and DiffeRential Evolution Adaptive Metropolis (DREAM) [51].

In this study, the SWAT model was calibrated/validated by the measurement data from the gauge station (U.S.G.S. 08470142), which is $58 \mathrm{~km}$ west of the ACW outlet. A total 14 parameters were altered for flow calibration, and for sediment. The same set of calibrated streamflow parameters was used for all scenarios and the sediment parameters were calibrated in each scenario. The parameters and the recommended ranges are listed in Appendix B and ??.

The Nash-Sutcliffe Efficiency coefficient (NSE) was used as the objective function to determine model goodness-of-fit. NSE has been implemented broadly as the primary statistical measure in the field of watershed modeling [52,53]. The values of NSE may range from $-\infty$ to one which represent the worst and the best model performance. In Equation (8), $y_{i}^{\text {Obs }}$ is the observation data at time step $i ; y_{i}^{\text {Sim }}$ is the model predictions at time step $i ; y_{i}^{\text {Mean }}$ is the mean of observation data at time step $i$; and $N$ is the time span of total time steps. Perfect simulation is achieved when NSE equals one, while negative values of NSE are generally regarded as poor performance. In this study, NSE was modified for the auto-calibration process [38] so that a value of zero indicates a perfect fit. In Equation (9), the objective function represents the integrated value of $(1-$ NSE) for targeted output variables (e.g., streamflow and sediment), where $O F$ is the value of the objective function; $N S E_{v}$ is the value of NSE of variable $v$; and $V$ is the total number of variables.

$$
\begin{gathered}
N S E=1-\frac{\sum_{i=1}^{N}\left(y_{i}^{\text {Obs }}-y_{i}^{\text {Sim }}\right)^{2}}{\sum_{i=1}^{N}\left(y_{i}^{\text {Obs }}-y_{i}^{\text {Mean }}\right)^{2}} \\
O F=\sum_{v=1}^{V}\left(1-N S E_{v}\right)
\end{gathered}
$$

It is difficult to estimate uncertainty in a deterministic model such as SWAT, therefore, the inclusion rate and spread were exerted to quantify the comparative level of uncertainty among scenarios. Spread is the average width of the $95 \%$ confidence interval along simulated temporal series. Since the width of confidence intervals may change over temporal series, it is a lot easier to compare levels of uncertainty by averaged width (which is defined as "spread"). On the other hand, the inclusion rate is calculated by the percentage of observed data located within $95 \%$ confidence intervals of modeling outputs (calculated by sorting simulation outputs at each time step using empirical probability density function). If there are 10 observation points and only seven of the total are located within the confidence intervals, the inclusion rate is going to be $70 \%$. More details and applications of the inclusion rate and spread can be found in Yen [50], Yen et al. [49].

\section{Results}

\subsection{Comprehensive Comparisons by Objective Function Values}

Figure 3A presents the overall performance for objective functions (optimized for sediment calibration) along with the model iteration for all four scenarios. The convergence speed was fairly varied with different scenarios where Scenario 02 reached a stable objective function value slower than other scenarios. After 1500 iteration times, no improvements (in terms of objective function values 
that did not change for more than $0.1 \%$ of the previous one within 1000 runs) were made in any of the scenarios. Figure 3B shows the best objective function values among the four scenarios. Scenario 04 (Yang equation) generated the best objective function, while Scenario 3 (Molinas and Wu equation) yielded the worst objective function. By comparing the performance of objective function values, the Yang equation fitted the measured data best. On the other hand, it is also necessary to consider other statistical measures (since there are other methods used to evaluate model performance in this study), which will be further discussed in later sections.

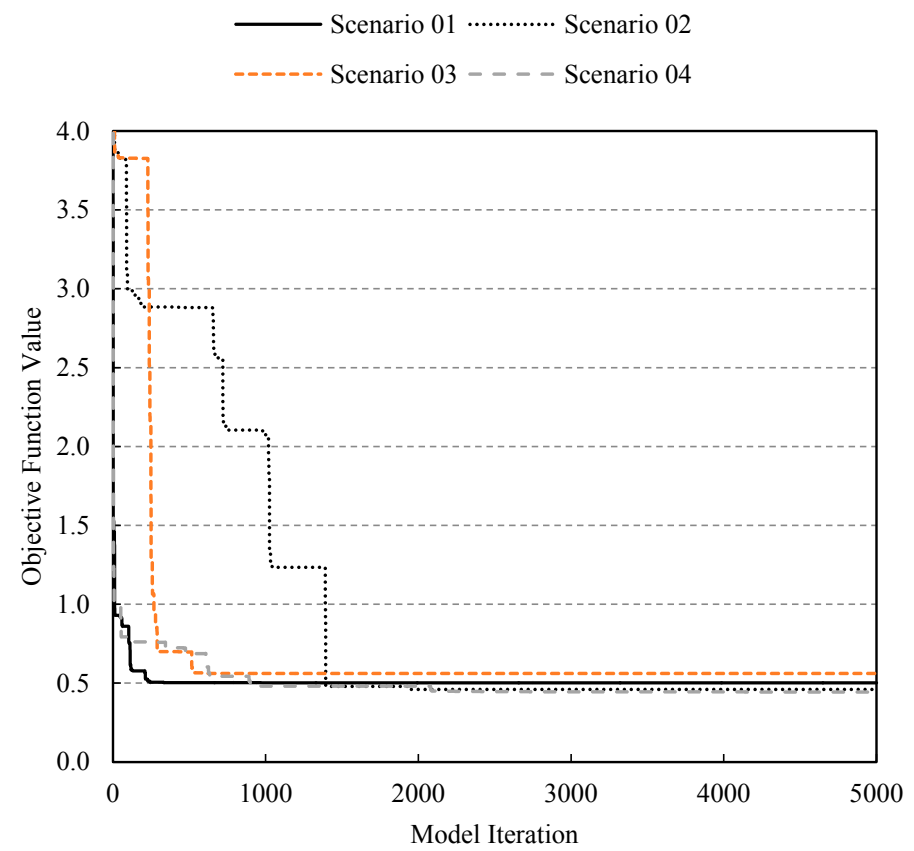

(A)

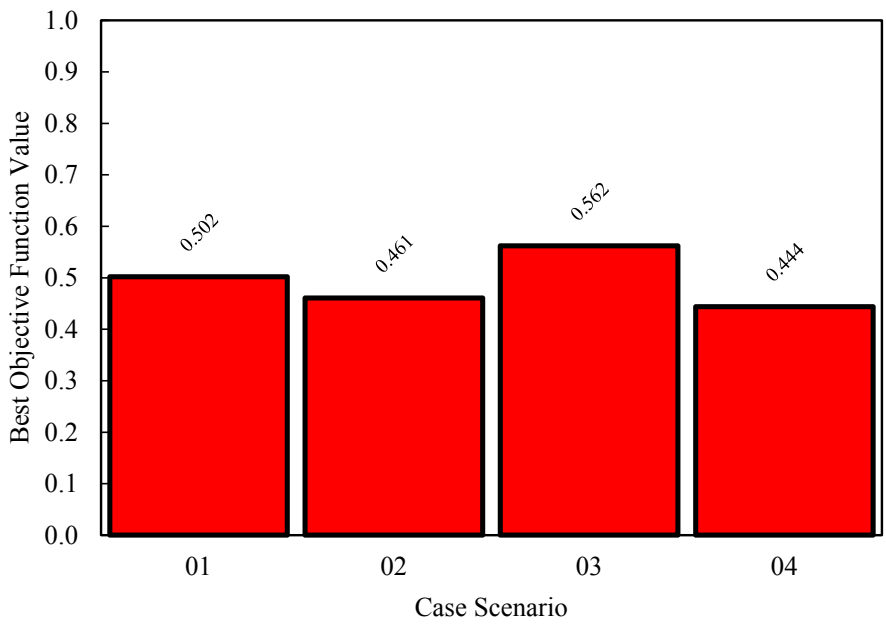

(B)

Figure 3. General performance of objective function values in all case scenarios (Scenario 01: Bagnold; Scenario 02: Kodoatie; Scenario 03: Molinas and Wu; Scenario 04: Yang): (A) The processes of convergence during auto-calibration whereas no substantial improvements can be found after 1500 iterations; (B) The final converged values of objective function are 0.502/0.461/0.562/0.444 for four scenarios respectively; the Yang equation performed better than the other methods in terms of optimality for objective function. 


\subsection{Evaluation of Model Performance on Streamflow and Sediment Predictions}

In Figure 3A,B, model predictions of streamflow and sediment loadings were evaluated in terms of NSE and PBIAS (percent bias). NSE values for streamflow were close to 0.69 and 0.56 for calibration and validation periods, respectively, in all four scenarios (Figure 4A). PBIAS was relatively low at less than or equal to $7 \%$ for streamflow for both evaluation periods in all four scenarios (Figure 4B). NSE values for sediment, however, were better for Scenarios 02 (Kodoatie), and 04 (Yang)—at approximately 0.85-than for Scenarios 01 (Bagnold) and 03 (Molinas and Wu).

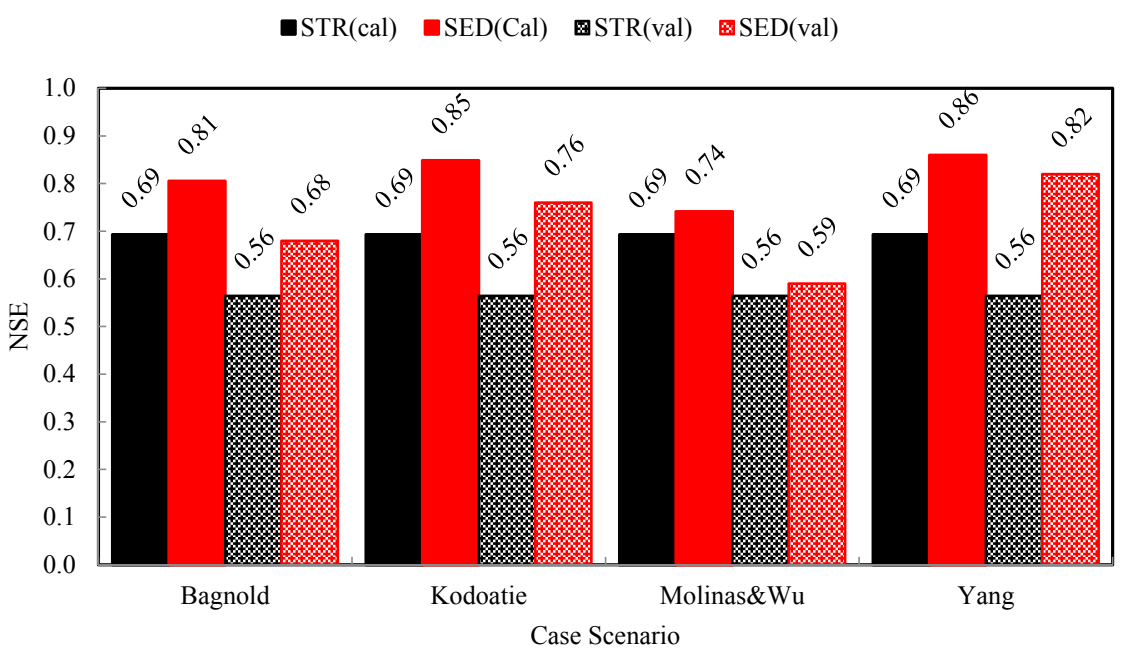

(A)

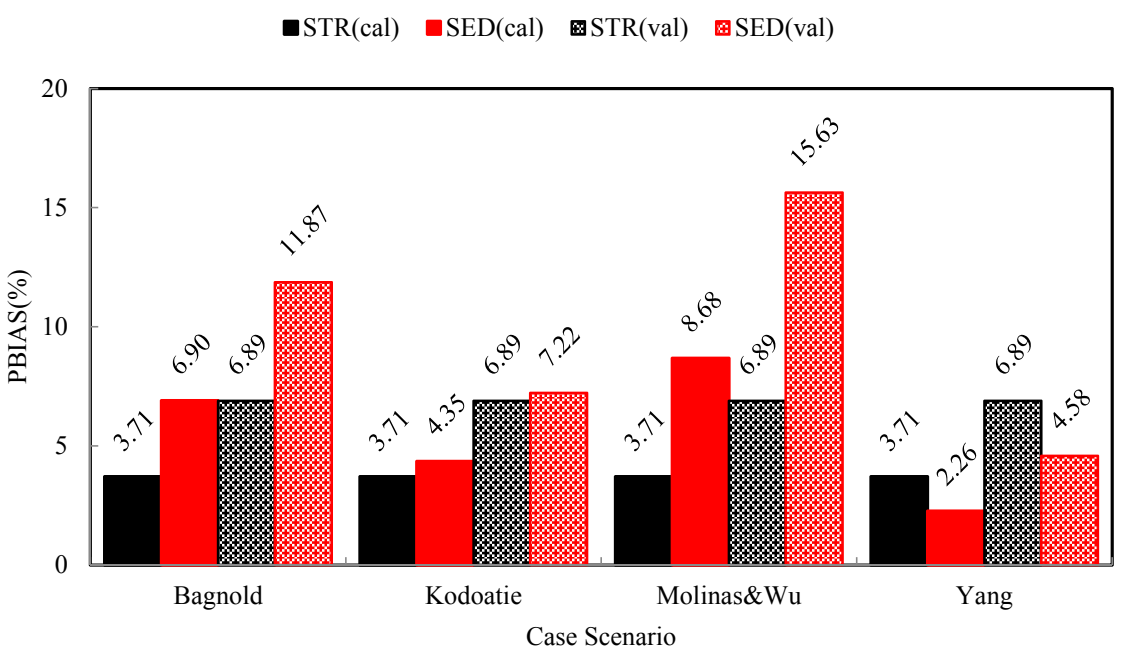

(B)

Figure 4. Best solutions (calibration and validation) of error statistics in four scenarios (Scenario 01: Bagnold; Scenario 02: Kodoatie; Scenario 03: Molinas and Wu; Scenario 04: Yang): (A) Nash-Sutcliffe efficiency coefficient; (B) PBIAS. (STR(cal): Error statistics of streamflow in the calibration period (2002-2003); SED(cal): Error statistics for sediment in the calibration period (2002-2003); STR(val): Error statistics of streamflow in the validation period (2004-2005); SED(val): Error statistics for sediment in the validation period (2004-2005).

PBIAS values for sediment exhibited the same trend (in terms of statistical values and also the relative differences among scenarios) in both the calibration and validation periods. In the calibration period, PBIAS for sediment was less than 5\% for Scenarios 02 (Kodoatie) and 04 (Yang), compared 
to $7 \%$ for Scenario 01 (Bagnold) and almost 9\% for Scenario 03 (Molinas and $\mathrm{Wu}$ ). In the validation period, Scenario 04 (Yang) performed the best, followed by Scenarios 02, 01, and 03. According to the guidelines for model performance, statistics recommended by Moriasi et al. [54] (one may also take advantage of the latest and more detailed guidelines in Moriasi et al. [55]), the best results from Scenarios 02 and 04 were considered "Very Good," while results from Scenarios 01 and 03 were classified as "Good." The results of error statistics were consistent with the overall performance of objective function values. The Yang equation generated the best sediment predictions, while the Molinas and Wu equation yielded the worst sediment predictions. Details of each method were further investigated in the following section.

Comparisons of simulated and observed values were shown in Figure 5A,B. As stated previously, streamflow predictions were fairly close among all scenarios either in NSE or PBIAS. In Figure 5A, the simulated streamflow approximated observed flow in all four scenarios. The peak flows in September and December 2002 were slightly underestimated, while the recession limbs during August and September 2003 were slightly overestimated. In general, the simulated daily streamflow performed well in both low and high conditions. In Figure 5B, simulated sediment under Scenarios 02 and 04 showed similar trends to the other two scenarios in time series. Considerable underestimation (around $50 \%$ underestimation between Scenario 03 and the observation) can be found in the early stage of Scenario 03. The performance of sediment predictions during high flow conditions was closer to observed data than during low flow periods, which can be explained by the fact that the objective function (NSE) was designed to capture peak events. The differences of streamflow and sediment processes among scenarios were consistent with the corresponding statistics.

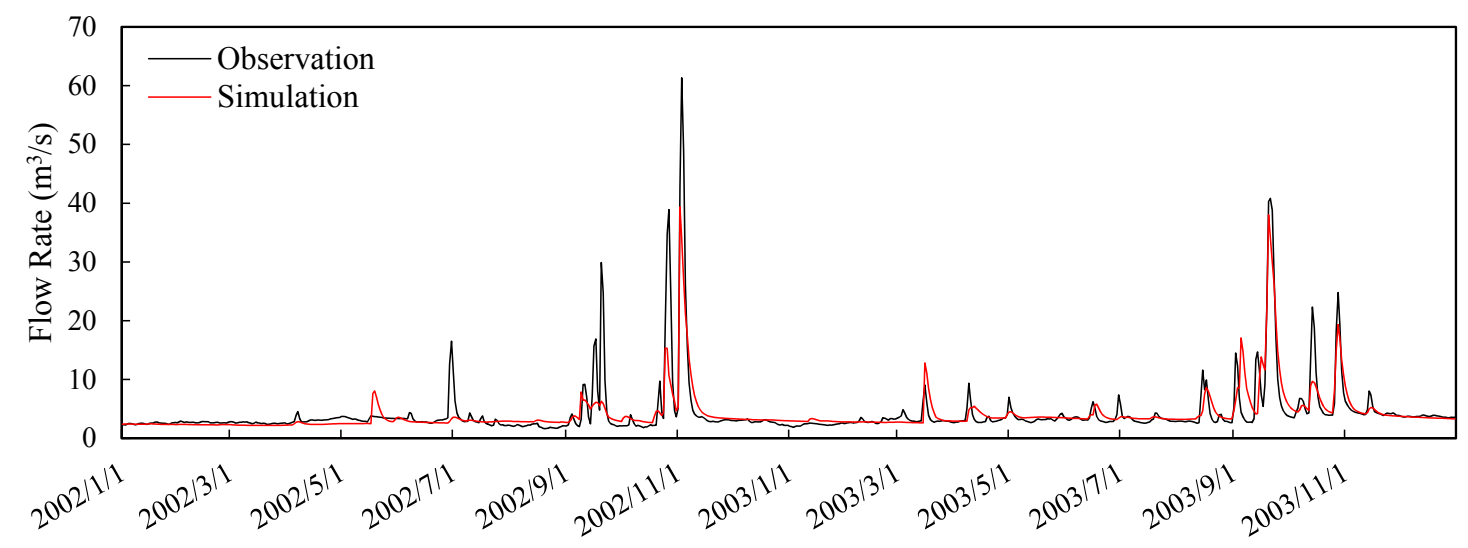

(A)

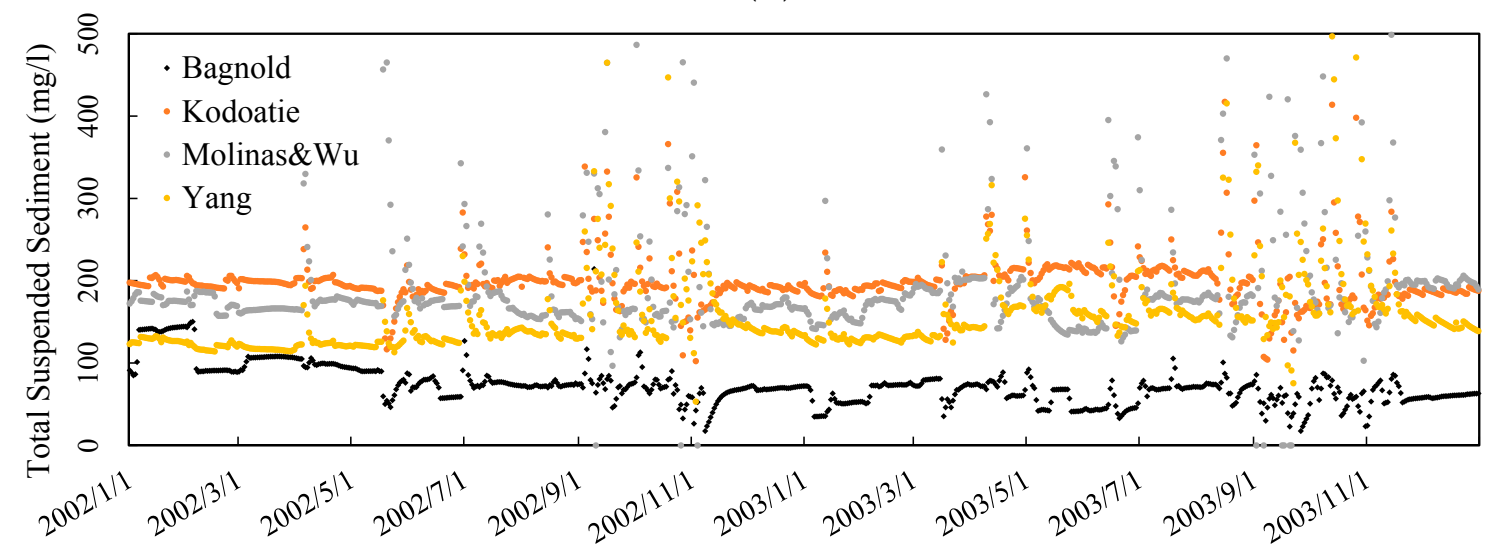

(B)

Figure 5. Cont. 


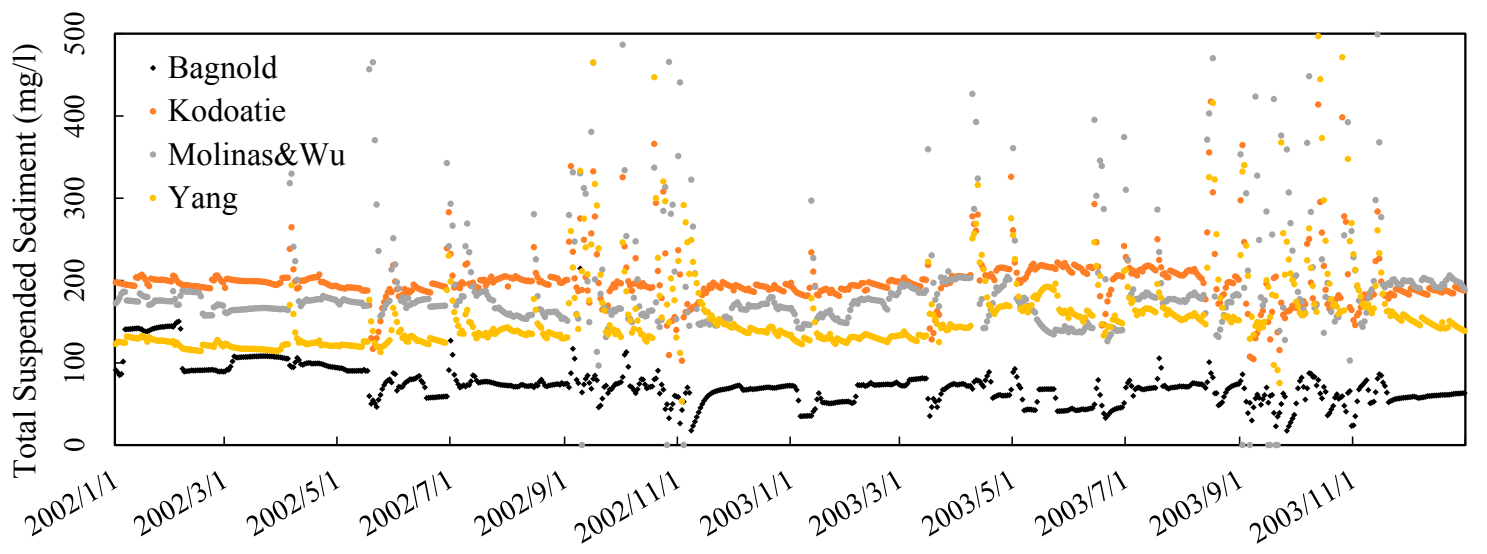

(C)

Figure 5. Best results in (A) daily streamflow (flow rate); (B) monthly sediment load; and (C) sediment concentration of total suspended sediment, by the four sediment equations in the SWAT (Soil and Water Assessment Tool) model (Scenario 01: Bagnold; Scenario 02: Kodoatie; Scenario 03: Molinas and $\mathrm{Wu}$; Scenario 04: Yang).

\subsection{Evaluation of Sediment Concentration and Sediment Budget}

Figure $5 \mathrm{~A}-\mathrm{C}$ demonstrated that, while all four equations generated comparable streamflow and sediment load trends, the total suspended sediment (TSS) concentration varied significantly between equations. In SWAT, TSS consisted only of silt and clay, while the total sediment loads contained all particles. Only 35\% of the total sediment loads from the Yang equation were silt and clay, while almost all total sediment loads from the other three equations were silt and clay. Accordingly, the Yang equation, which was developed to simulate large particles such as sand and gravel, generated lower sediment concentrations than did the Molinas and Wu equation and the Kodoatie equation. The Bagnold equation yielded the lowest TSS concentrations overall, but it is important to note that, during high flow conditions, TSS concentrations rose when applying the Bagnold equation (Figure 5B).

In considering why four equations that generated comparable sediment loads can yield different TSS concentrations, it is important to consider sediment sources and sinks associated with each respective equation. As shown in Figure 6, the Bagnold equation had significant bank erosion and minimal bed erosion, while bed erosion exceeded bank erosion in all three other equations. The Molinas and $\mathrm{Wu}$ equation generated the most sediment movement (2.62 ton/ha), as well as the greatest erosion (1.76 ton/ha), resuspension, and deposition. In general, surface erosion and point sources contributed an unsubstantial portion of sediment yield. Notable findings here will be further investigated in the next section. 


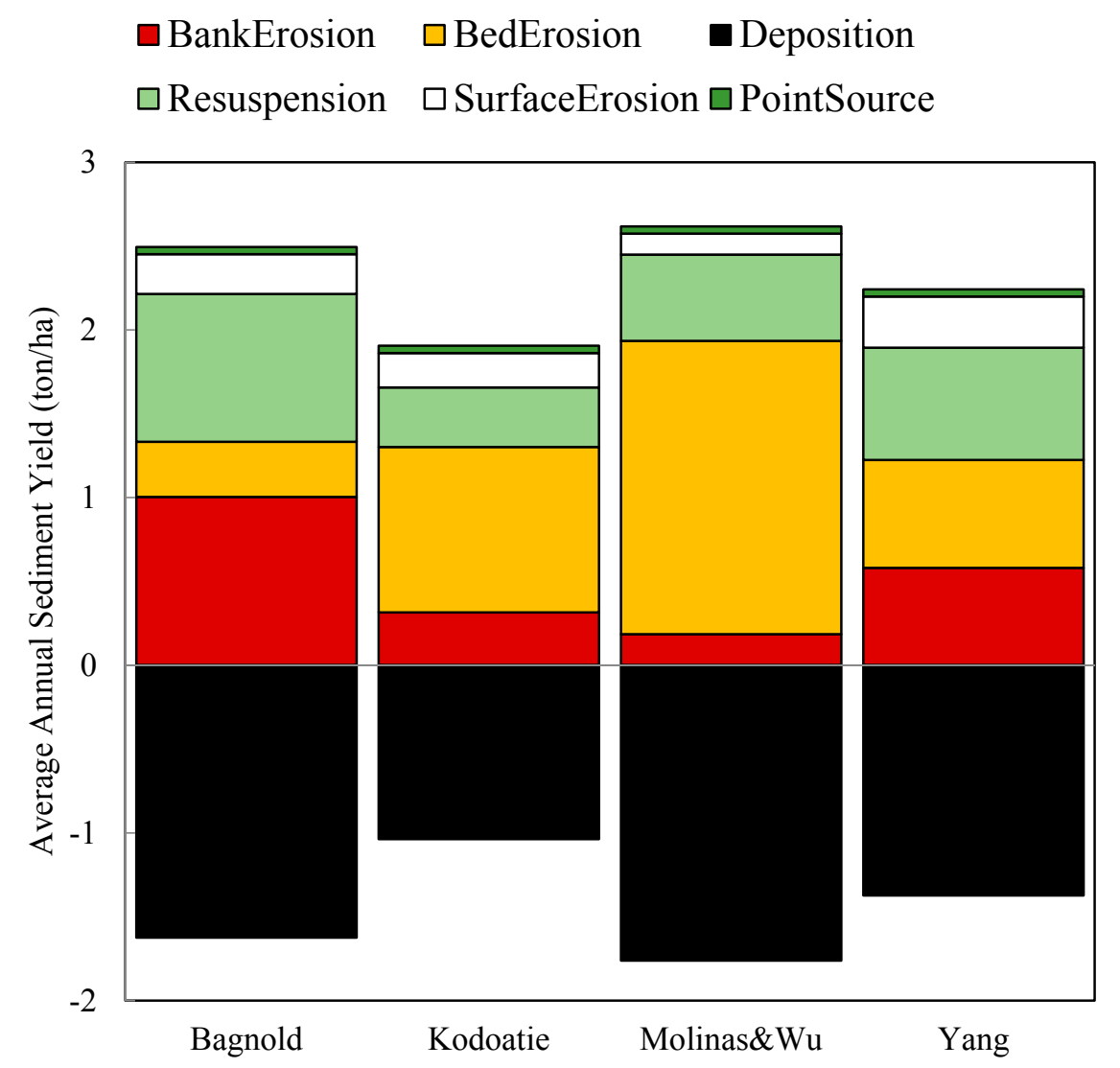

Figure 6. Best results of average annual sediment sources and sinks for the four sediment routing equations.

\subsection{Uncertainty Analysis}

The predictive uncertainty for streamflow and sediment were evaluated using the inclusion rate and spread, and the results were shown in Table 1 . Since all scenarios share mutual streamflow calibration results, the inclusion rate and spread are essentially the same. For sediment predictions, Scenarios 02 and 04 (the best two scenarios) performed similarly while a considerable increase of spread and the inclusion rate can be found in Scenario 01 and 03 . In general, the wider spread identified in Scenarios 01 and 03 increased the corresponding inclusion rate.

Table 1. Inclusion rate and spread of measured streamflow and sediment within the $95 \%$ confidence intervals of the simulation period (2002-2003).

\begin{tabular}{ccccc}
\hline \multirow{2}{*}{ Scenario } & \multicolumn{2}{c}{ Inclusion Rate (\%) } & \multicolumn{2}{c}{ Spread } \\
\cline { 2 - 5 } & Streamflow & Sediment & Streamflow & Sediment \\
\hline Scenario 01 & 49.59 & 62.50 & 1.815 & 0.046 \\
Scenario 02 & 49.59 & 35.42 & 1.815 & 0.033 \\
Scenario 03 & 49.59 & 54.17 & 1.815 & 0.040 \\
Scenario 04 & 49.59 & 31.25 & 1.815 & 0.029 \\
\hline
\end{tabular}

Notes: Inclusion rate (\%): Percentage of measured data located within the $95 \%$ confidence intervals. Spread: Average width of the corresponding uncertainty band along the predicted time series. The units for streamflow and sediment are $\mathrm{m}^{3} / \mathrm{s}$ (cubic meter per second), and tons/ha (tons per hectare) respectively.

A higher inclusion rate means that more of the observed data set is located within the $95 \%$ confidence interval of the model simulation, which seems to indicate reduced uncertainty. However, the associated spread increases with higher inclusion rates, suggesting that it is harder for the 
auto-calibration technique to find better solutions in the given watershed modeling project. Therefore, a higher inclusion rate may also indicate that the corresponding uncertainty has increased. In this study, the importance of greater or lesser uncertainty relied upon relative comparisons among scenarios instead of a quantified, stand-alone measurement. Accordingly, it is not feasible to objectively identify which scenario is superior based on the available evidence. Scientists and stakeholders should consider the potential margins while conducting alternative approaches.

\section{Discussion}

\subsection{Similarities and Differences during Calibration}

In this study, it was found that all four sediment routing methods produced similar calibrated sediment yields in the targeted watershed, but sediment concentration differed substantially. The four sediment routing methods estimated quite different sources and sinks of sediment throughout the watershed. In the Bagnold equation, erosion occurred mainly on the stream banks, while it was primarily bed erosion in the other equations. In the Yang equation, bed materials were calibrated to better simulate sandy conditions; therefore, the total sediment loads contained more coarse materials, which SWAT excluded from TSS concentrations, than silt and clay. In the other equations, bank and bed materials were calibrated to be loamy, and total sediment loads were essentially silt and clay, which was a part of the primary sources to TSS concentrations in SWAT.

The discrepancies in sediment load composition are not completely due to the differences in equation theory. The auto-calibration approach, which selects parameter values without any regard of physical meaning (see Appendix B for the best parameter sets in the four scenarios), may contribute to erroneous differences in sediment load composition. The mechanism for stream bank and stream bed erosion was controlled by $\mathrm{CH}$ _COV1 and $\mathrm{CH}$ _COV2 in the routing $\left({ }^{*}\right.$.rte) files, which are more prone to erosion with lower parameter values (if $\mathrm{CH}_{-} \mathrm{EQU}>0$ ). Therefore, one may control erroneous erosion of the river bank and bed by specifying different ranges for stream bank and stream bed.

The fractions of silt and clay in total sediment loads were controlled by CH_BNK_D50 and CH_BED_D50, respectively. In terms of calibrated bed sediment size, the Bagnold and the Kodoatie equations performed well during the auto-calibration processes. CH_BED_D50 values (which were not yet available in literature) were $1.267 \mu \mathrm{m}$, medium clay, and $49.24 \mu \mathrm{m}$, coarse silt, for Kodoatie and Bagnold, respectively. However, the former was developed for sediment from silt to gravel, while the latter was for sandy rivers. The other two scenarios included suitable bed sediment sizes for the application sediment transport equations.

For study areas with missing TSS data or expert knowledge of sediment transport pathways, one cannot conclusively judge which results best suit the catchment. As stated in a previous study [56], selection of alternative functions within a complex watershed simulation model could significantly impact model predictions. Ideally, users should apply both extensive TSS data and thorough knowledge of a study area as they choose a sediment routing equation and parameter ranges measurements that suit their specific goals. When complete data are not available, users should consider how their sediment routing equation and parameter range choices may affect results.

\subsection{Comparisons of Equation Theories and Applications}

There were both resuspension and deposition by all equations, due to the sediment routing processes in the SWAT model, which were the same for all equations (SWAT conducts sediment routing in main reaches and channels according to the sediment transport capacity). In studies of the field isotope investigation, most stream erosion was redeposited within the streams, and much of the TSS in the water column came from resuspended sediments within streams $[57,58]$. The Kodoatie equation has been tested against stream bed materials of all sizes, whereas Bagnold, Molinas and $\mathrm{Wu}$ and Yang equations were developed for large sand-bed rivers [24,25,59]. In addition, the Bagnold and Yang equations were widely applied in large rivers. The Kodoatie equation and the Molinas and $\mathrm{Wu}$ 
equations were not applied as much as the other two equations. Intuitively, the Kodoatie equation should have performed the best because it could incorporate the full range of sediment sizes. However, Yang's equation performed overall the best, followed by the Kodoatie, Bagnold, and Molinas and Wu equations. It implied that the selection of sediment transport equations should be determined based on more than which equation can incorporate more sediment material sizes. One should also consider other issues such as (i) how many associated parameters are available to properly reflect actual watershed behavior (e.g., actual measured values of bank erosion parameters are available or perhaps an additional calibration process is required); and (ii) how well the integrated watershed model (in this case, the SWAT model) could simulate the sediment transport process by alternative methods (e.g., in other cases, surface runoff routines can be calculated by curve number procedure [60] or the Green and Ampt infiltration approach [61] via SWAT [56]).

In SWAT, the optional modified Bagnold equation is associated with the highest inclusion rate of sediment (Table 1) as well as the highest level of uncertainty. SWAT allowed more parameters to be calibrated for the modified Bagnold equation than for the other three alternative equations, because it shared the same parameters as the default simplified Bagnold equation [27]. Many parameters in the three other equations were hard coded in the SWAT model and thus cannot be calibrated. Parameters for the Bagnold equation should be more dependent on field survey data than the three other equations to reduce uncertainty using SWAT as the modeling tool.

The fundamental approach to improve the simulation results is to have more observation data of the targeted watershed, such as sediment sizes, channel erosion factors, and channel cover factors. It is advised to use measured data (parameters) to conduct relevant comparisons and analysis. However, it is difficult to evaluate some equations in depth due to limited information about the study area. In many cases, it may not be feasible economically or due to time constraints. These challenges may be addressed by automatic calibration techniques, which were developed to address the growing number of unknown values of model parameters.

\section{Conclusions}

In this study, the impacts of alternative maximum sediment transport functions on sediment prediction in the SWAT model were evaluated by IPEAT. Four sediment routing methods (modified Bagnold equation, Kodoatie equation, Molinas and Wu equation, and Yang sand and gravel equation) in the SWAT model were calibrated and validated via daily flow and monthly sediment loads in the ACW using IPEAT as the primary tool in conducting parameter estimation and uncertainty analysis. The Yang and the Kodoatie equations generated better predictions in terms of commonly used statistical measures. In addition, the associated uncertainty is relatively lower for the Yang and the Kodoatie equations. Uncertainty of model results from these two equations was smaller, with a higher inclusion rate and smaller spread, than results from other equations. In the Yang equation, both sand and gravel are applicable with calibrated sediment size, while the Kodoatie equation is not suitable for the calibrated values.

The major finding of this study is that it is possible for the four sediment transport equations to yield similar sediment yields, even in a watershed that does not have a complete set of observation data (e.g., measurement of sediment sizes, channel bank information). However, the use of alternative functions may not directly impact desired results due to varying TSS concentrations, the associated source and sink terms, or a complex watershed simulation model with multiple calculation procedures in specific output variables. In practice, it may be difficult to measure or even estimate values of channel or river bed parameters. Auto-calibration may provide an efficient technology to calibrate model parameters within a limited timeframe. However, the embedded physical meanings could contribute to erroneous, biased results if the tool (e.g., IPEAT in this study) is implemented blindly. As scientists, engineers, and decision makers (not limited to politicians) contemplate policy issues related to sediment transport, they should evaluate the applicability of model results to policy on a case-by-case basis. 
Input data, parameter estimation, and selection of sediment transport equation contribute to what one can and cannot conclusively determine from the results of a SWAT modeling study.

Acknowledgments: This project study was supported funded by grants from the Incheon National University International Cooperative Research Grant in 2016, the United States Department of Agriculture-Natural Resources Conservation Service (USDA-NRCS) Conservation Effects Assessment Project (CEAP)—Wildlife and Cropland components, and from Korea Ministry of Environment (MOE) as the Environmental Health Action Program (Grant No. 2015001370003). The authors also appreciate the continuous support from the Ministry of Science and Technology in Taiwan, Republic of China (MOST 103-2811-M-006-050).

Author Contributions: Haw Yen conducted the primary work in this study (watershed modeling, analysis and the major writing of the manuscript). Shenglan Lu performed the sediment transport analysis. QingYu Feng, Ruoyu Wang and Jungang Gao, were helping to strengthen the quality of the work in terms of data management and evaluation of the results. All authors were involved in the preparation and review of the manuscript.

Conflicts of Interest: The authors declare no conflict of interest.

\section{Appendix A.}

Table A1. Streamflow parameters applied in all case scenarios.

\begin{tabular}{|c|c|c|c|c|c|}
\hline Parameters & $\begin{array}{l}\text { Input } \\
\text { File }\end{array}$ & Units & Range & $\begin{array}{l}\text { Calibrated } \\
\text { Values }\end{array}$ & Description \\
\hline EPCO &.$b s n$ & - & $0-1$ & 0.454 & Plant uptake compensation factor \\
\hline SURLAG & bsn & Day & $1-24$ & 6.865 & Surface runoff lag time \\
\hline ALPHA_BF &. $\mathrm{gw}$ & 1/Day & $0-1$ & 0.764 & Baseflow alpha factor \\
\hline GW_DELAY &. $\mathrm{gw}$ & Day & $0-500$ & 98.22 & Groundwater delay \\
\hline GW_REVAP &.$g w$ & - & $0.02-0.2$ & 0.042 & Groundwater "revap" coefficient \\
\hline GWQMN &. $\mathrm{gw}$ & $\begin{array}{l}\mathrm{mm} \\
\mathrm{H}_{2} \mathrm{O}\end{array}$ & $0-5000$ & 28.16 & $\begin{array}{l}\text { Threshold depth of water in the shallow } \\
\text { aquifer required for return flow to occur }\end{array}$ \\
\hline $\mathrm{ESCO}$ & hru & - & $0-1$ & 0.403 & Soil evaporation compensation factor \\
\hline CN_F & .mgt & $\%$ & \pm 10 & 9.144 & Initial SCS CN II value \\
\hline $\mathrm{CH}-\mathrm{K} 2$ & .rte & $\mathrm{mm} / \mathrm{h}$ & $-0.01-500$ & 85.60 & Effective hydraulic conductivity in main channel alluvium \\
\hline CH_N2 & .rte & - & $-0.01-0.3$ & 0.070 & Manning's " $n$ " value for the main channel \\
\hline SOL_AWC & .sol & $\%$ & \pm 10 & 8.522 & Available water capacity of the soil layer \\
\hline SOL_K &. sol & $\%$ & \pm 10 & 8.997 & Saturated hydraulic conductivity \\
\hline $\mathrm{CH} \_\mathrm{K} 1$ & sub & $\mathrm{mm} / \mathrm{h}$ & $0-300$ & 32.06 & Effective hydraulic conductivity in tributary channel alluvium \\
\hline CH_N1 & sub & - & $0.01-30$ & 0.191 & Manning's " $n$ " value for the tributary channels \\
\hline
\end{tabular}

Notes: Parameter values for CN_F, SOL_AWC, and SOL_K, are the changes of fraction from default values. 


\section{Appendix B.}

Table B1. Calibrated parameters for sediment predictions in all case scenarios.

\begin{tabular}{|c|c|c|c|c|c|c|c|c|}
\hline Parameter & Input File & Unit & Scenario 01 & Scenario 02 & Scenario 03 & Scenario 04 & Range & Description \\
\hline ADJ_PKR & .bsn & - & 0.549 & 0.464 & 1.290 & 1.195 & $0-2$ & $\begin{array}{l}\text { Peak rate adjustment factor for sediment } \\
\text { routing in the sub-basin (tributary channels) }\end{array}$ \\
\hline PRF & .bsn & - & 1.713 & 0.755 & 0.089 & 1.257 & $0-2$ & $\begin{array}{l}\text { Peak rate adjustment factor for } \\
\text { sediment routing in the main channel }\end{array}$ \\
\hline SPCON & .bsn & - & 0.0074 & 0.0067 & 0.0059 & 0.0067 & $0.0001-0.01$ & $\begin{array}{l}\text { Linear parameter for calculating the } \\
\text { maximum amount of sediment that can be } \\
\text { re-entrained during channel sediment routing }\end{array}$ \\
\hline SPEXP & .bsn & - & 1.995 & 1.051 & 1.760 & 1.761 & $1.0-1.5$ & $\begin{array}{l}\text { Exponent parameter for calculating sediment } \\
\text { re-entrained in channel sediment routing }\end{array}$ \\
\hline CH_BED_BD & .rte & $\mathrm{g} / \mathrm{cc}$ & 1.811 & 1.386 & 1.617 & 1.110 & $1.1-1.9$ & Bulk density of channel bed sediment \\
\hline CH_BED_D50 & .rte & $\mu \mathrm{m}$ & 4650 & 1.267 & 49.24 & 8241 & $1-10,000$ & $\begin{array}{l}\text { D50 median particle size diameter } \\
\text { of channel bed sediment }\end{array}$ \\
\hline CH_BNK_BD & .rte & $\mathrm{g} / \mathrm{cc}$ & 1.118 & 1.118 & 1.335 & 1.172 & $1.1-1.9$ & Bulk density of channel bank sediment \\
\hline CH_BNK_D50 & .rte & $\mu \mathrm{m}$ & 2592 & 1868 & 1677 & 1550 & $1-10,000$ & $\begin{array}{l}\text { D50 median particle size diameter } \\
\text { of channel bank sediment }\end{array}$ \\
\hline CH_COV1 & .rte & - & 0.1807 & 3.7340 & 4.2880 & 4.4340 & $0-5$ & Channel erodibility factor \\
\hline CH_COV2 & .rte & - & 2.3600 & 0.0006 & 0.0528 & 0.4123 & $0-5$ & Channel cover factor \\
\hline
\end{tabular}




\section{References}

1. Arnold, J.G.; Allen, P.M.; Bernhardt, G.A. Comprehensive surface-groundwater flow model. J. Hydrol. 1993, 142, 47-69. [CrossRef]

2. Arnold, J.G.; Kiniry, J.R.; Srinivasan, R.; Williams, J.R.; Haney, E.B.; Neitsch, S.L. Soil and Water Assessment Tool Input/Output Documentation 2012; Texas Water Resources Institute Technical Report No. 439; Texas A\&M University System: College Station, TX, USA, 2012.

3. Niraula, R.; Kalin, L.; Wang, R.; Srivastava, P. Determining nutrient and sediment critical source areas with SWAT model: Effect of lumped calibration. Trans. ASABE 2012, 55, 137-147. [CrossRef]

4. Johnson, M.V.V.; Norfleet, M.L.; Atwood, J.D.; Behrman, K.D.; Kiniry, J.R.; Arnold, J.G.; White, M.J.; Williams, J. The Conservation Effects Assessment Project (CEAP): A national scale natural resources and conservation needs assessment and decision support tool. IOP Conf. Ser. Earth Environ. Sci. 2015, 25. [CrossRef]

5. Scavia, D.; Kalcic, M.; Muenich, R.L.; Aloysius, N.; Arnold, J.; Boles, C.; Confessor, R.; De Pinto, J.; Gildow, M.; Martin, J.; et al. Informing Lake Erie Agriculture Nutrient Management via Scenario Evaluation; University of Michigan: Ann Arbor, MI, USA, 2016; Available online: http://graham.umich.edu/water/project/eriewestern-basin (accessed on 23 January 2017).

6. Sharifi, A.; Kalin, L.; Hantush, M.M.; Isik, S.; Jordan, T. Carbon export and dynamics from flooded wetlands: A modeling approach. Ecol. Model. 2013, 263, 196-210. [CrossRef]

7. Tasdighi, A.; Arabi, M.; Osmond, D.L. The relationship between land use and vulnerability to nitrogen and phosphorus pollution in an urban watershed. J. Environ. Qual. 2017, 46, 113-122. [CrossRef]

8. Yen, H.; White, M.J.; Arnold, J.G.; Keitzer, S.C.; Johnson, M.V.; Atwood, J.D.; Daggupati, P.; Herbert, M.E.; Sowa, S.P.; Ludsin, S.A.; et al. Western Lake Erie Basin: Soft-data-constrained, NHDPlus resolution watershed modeling and exploration of applicable conservation scenarios. Sci. Total Environ. 2016, 569-570, 1265-1281. [CrossRef] [PubMed]

9. Sharifi, A.; Lang, M.W.; McCarty, G.W.; Sadeghi, A.M.; Lee, S.; Yen, H.; Rabenhorst, M.C.; Jeong, J.; Yeo, I.-Y. Improving model prediction reliability through enhanced representation of wetland soil processes and constrained model auto calibration-A paired watershed study. J. Hydrol. 2016, 541, 1088-1103. [CrossRef]

10. Gassman, P.W.; Sadeghi, A.M.; Srinivasan, R. Applications of the SWAT Model special section: Overview and insights. J. Environ. Qual. 2014, 43, 1-8. [CrossRef] [PubMed]

11. Woodbury, J.D.; Shoemaker, C.A.; Easton, Z.M.; Cowan, D.M. Application of SWAT with and without Variable Source Area Hydrology to a Large Watershed. JAWRA J. Am. Water Resour. Assoc. 2014, 50, 42-56. [CrossRef]

12. Carvalho-Santos, C.; Nunes, J.P.; Monteiro, A.T.; Hein, L.; Honrado, J.P. Assessing the effects of land cover and future climate conditions on the provision of hydrological services in a medium-sized watershed of Portugal. Hydrol. Process. 2016, 30, 720-738. [CrossRef]

13. Bärlund, I.; Kirkkala, T.; Malve, O.; Kämäri, J. Assessing SWAT model performance in the evaluation of management actions for the implementation of the Water Framework Directive in a Finnish catchment. Environ. Model. Softw. 2007, 22, 719-724. [CrossRef]

14. Flynn, K.F.; Van Liew, M.W. Evaluation of swat for sediment prediction in a mountainous snowmelt-dominated catchment. Trans. ASABE 2011, 54, 113-122. [CrossRef]

15. Mishra, A.; Kar, S. Modeling hydrologic processes and NPS pollution in a small watershed in subhumid subtropics using SWAT. J. Hydrol. Eng. 2012, 17, 445-454. [CrossRef]

16. Lam, Q.; Schmalz, B.; Fohrer, N. The impact of agricultural Best Management Practices on water quality in a North German lowland catchment. Environ. Monit. Assess. 2011, 183, 351-379. [CrossRef] [PubMed]

17. Wu, Y.; Chen, J. Modeling of soil erosion and sediment transport in the East River Basin in Southern China. Sci. Total Environ. 2012, 441, 159-168. [CrossRef] [PubMed]

18. Walling, D.E. The sediment delivery problem. J. Hydrol. 1983, 65, 209-237. [CrossRef]

19. Lu, S.; Kayastha, N.; Thodsen, H.; van Griensven, A.; Andersen, H.E. Multiobjective Calibration for Comparing Channel Sediment Routing Models in the Soil and Water Assessment Tool. J. Environ. Qual. 2014, 43, 110-120. [CrossRef] [PubMed] 
20. Walling, D.E. The Impact of Global Change on Erosion and Sediment Transport by Rivers: Curretn Progress and Future Challenges; World Water Assessment Programme; United Nation Educational, Scientific and Cultural Organization: Paris, France, 2009.

21. Bagnold, R.A. Bed load transport by natural rivers. Water Resour. Res. 1977, 13, 303-312. [CrossRef]

22. Neitsch, S.L.; Arnold, J.G.; Kiniry, J.R.; Williams, J.R. Soil and Water Assessment Tool Theoretical Documentation Version 2009; Texas Water Resources Institute Technical Report No. 406; Texas A\&M University System: College Station, TX, USA, 2011.

23. Kodoatie, R.J. Sediment Transport Relations in Alluvial Channels. Ph.D. Thesis, Colorado State University, Fort Collins, CO, USA, 2000.

24. Molinas, A.; Wu, B.S. Transport of sediment in large sand-bed rivers. J. Hydraul. Res. 2001, 39, $135-146$. [CrossRef]

25. Yang, C.T. Sediment Transport Theory and Practice; The McGraw-Hill Companies, Inc.: New York, NY, USA, 1996.

26. Williams, J.R. SPNM, a model for predicting sediment, phosphorus, and nitrogn yields from agricultural basins. Water Resour. Bull. 1980, 16, 843-848. [CrossRef]

27. Lu, S.; Kronvang, B.; Audet, J.; Trolle, D.; Andersen, H.E.; Thodsen, H.; van Griensven, A. Modelling sediment and total phosphorus export from a lowland catchment: Comparing sediment routing methods. Hydrol. Process. 2014. [CrossRef]

28. Wang, R.; Bowling, L.C.; Cherkauer, K.A. Estimation of the effects of climate variability on crop yield in the Midwest USA. Agric. For. Meteorol. 2016, 216, 141-156. [CrossRef]

29. Jha, M.K.; Gassman, P.W.; Arnold, J.G. Water quality modeling for the Raccoon River watershed using SWAT. Trans. ASAE 2007, 50, 479-493. [CrossRef]

30. Hoque, Y.M.; Hantush, M.M.; Govindaraju, R.S. On the scaling behavior of reliability-resilience-vulnerability indices in agricultural watersheds. Ecol. Indic. 2014, 40, 136-146. [CrossRef]

31. Wang, R.; Kalin, L. Responses of hydrological processes and water quality to land use/cover (LULC) and climate change in a coastal watershed. In Proceedings of the Second International Conference on Sustainable Systems and the Environment (ISSE'14), Sharjah, United Arab Emirates, 12-13 February 2014.

32. Butcher, J.B.; Johnson, T.E.; Nover, D.; Sarkar, S. Incorporating the effects of increased atmospheric $\mathrm{CO}_{2}$ in watershed model projections of climate change impacts. J. Hydrol. 2014, 513, 322-334. [CrossRef]

33. Daggupati, P.; Yen, H.; White, M.J.; Srinivasan, R.; Arnold, J.G.; Keitzer, C.S.; Sowa, S.P. Impact of model development, calibration and validation decisions on hydrological simulations in West Lake Erie Basin. Hydrol. Process. 2015. [CrossRef]

34. Wang, R.; Bowling, L.C.; Cherkauer, K.A.; Raj, C.; Her, Y.; Chaubey, I. Biophysical and hydrological effects of future climate change including trends in $\mathrm{CO}_{2}$, in the St. Joseph River watershed, Eastern Corn Belt. Agric. Water Manag. 2016. [CrossRef]

35. White, M.; Harmel, D.; Yen, H.; Arnold, J.; Gambone, M.; Haney, R. Development of Sediment and Nutrient Export Coefficients for U.S. Ecoregions. JAWRA J. Am. Water Resour. Assoc. 2015, 1-18. [CrossRef]

36. Wang, R.; Kalin, L.; Kuang, W.; Tian, H. Individual and combined effects of land use/cover and climate change on Wolf Bay Watershed Streamflow in Southern Alabama. Hydrol. Process. 2014. [CrossRef]

37. Kannan, N. SWAT Modeling of the Arroyo Colorado Watershed; TR-426; Texas Water Resources Institute: College Station, TX, USA, 2012.

38. Seo, M.-J.; Yen, H.; Jeong, J. Transferability of input parameters between SWAT 2009 and SWAT 2012. J. Environ. Qual. 2014, 43, 869-880. [CrossRef] [PubMed]

39. National Elevation Dataset. U.S. Geological Survey (USGS). Available online: http://ned.usgs.gov/ (accessed on 12 October 2016).

40. Gesch, D.; Evans, G.; Mauck, J.; Hutchinson, J.; Carswell, W.J., Jr. The National Map-Elevation: U.S. Geological Survey Fact Sheet 2009-3053. 2009; 4p. Available online: http:/ /ned.usgs.gov/ (accessed on 18 September 2013).

41. Rains, T.H.; Miranda, R.M. Simulation of Flow and Water Quality of the Arroyo Colorado, Texas, 1989-1999; United States Geological Survey-Water Resources Investigations Report, No: 02-4110; United States Geological Survey: Reston, VA, USA, 2002.

42. Harmel, R.D.; Cooper, R.J.; Slade, R.M.; Haney, R.L.; Arnold, J.G. Cumulative uncertainty in measured streamflow and water quality data for small watersheds. Trans. ASABE 2006, 49, 689-701. [CrossRef] 
43. Yen, H.; Hoque, Y.; Wang, X.; Harmel, R.D. Applications of Explicitly-Incorporated/Post-Processing Measurement Uncertainty in Watershed Modeling. JAWRA J. Am. Water Resour. Assoc. 2016, 52, 523-540. [CrossRef]

44. Runkel, R.; Crawford, C.; Cohn, T. Load ESTimator (LOADEST): A FORTRAN program for estimating constituent loads in streams and rivers. In US Geological Survey Techniques and Methods Book 4; US Geological Survey: Reston, VA, USA, 2004.

45. Eaton, B.C.; Millar, R.G. Optimal alluvial channel width under a bank stability constraint. Geomorphology 2004, 62, 35-45. [CrossRef]

46. Posada, G.L. Transport of Sands in Deep Rivers. Ph.D. Thesis, Department of Civil Engineering, Colorado State University, Fort Collins, CO, USA, 1995.

47. Yang, C.T. Incipient motion and sediment transport. J. Hydraul. Div. 1973, 99, 1679-1704.

48. Yang, C.T. Unit stream power equation for gravel. J. Hydraul. Div. 1984, 110, 1783-1797. [CrossRef]

49. Yen, H.; Wang, X.; Fontane, D.G.; Harmel, R.D.; Arabi, M. A framework for propagation of uncertainty contributed by parameterization, input data, model structure, and calibration/validation data in watershed modeling. Environ. Model. Softw. 2014, 54, 211-221. [CrossRef]

50. Yen, H. Confronting Input, Parameter, Structural, and Measurement Uncertainty in Multi-Site Multiple Responses Watershed Modeling Using Bayesian Inferences. Ph.D. Thesis, Colorado State University, Fort Collins, CO, USA, 2012.

51. Yen, H.; Jeong, J.; Tseng, W.; Kim, M.; Records, R.; Arabi, M. Computational procedure for evaluating sampling techniques on watershed model calibration. J. Hydrol. Eng. 2014. [CrossRef]

52. American Society of Civil Engineers (ASCE). Criteria for evaluation of watershed models, ASCE task committee on definition of criteria for evaluation of watershed models of the watershed management, irrigation, and drainage division. J. Irrig. Drain. Eng. 1993, 119, 429.

53. Servat, E.; Dezetter, A. Selection of calibration objective functions in the context of rainfall-runoff modeling in a Sudanese savannah area. Hydrol. Sci. J. 1991, 36, 307-330. [CrossRef]

54. Moriasi, D.N.; Arnold, J.G.; Liew, M.W.V.; Bingner, R.L.; Harmel, R.D.; Veith, T.L. Model evaluation guidelines for systematic quantification of accuracy in watershed simulations. Trans. ASABE 2007, 50, 885-900. [CrossRef]

55. Moriasi, D.N.; Gitau, M.W.; Pai, N.; Daggupati, P. Hydrologic and water quality models: Performance measures and evaluation criteria. Trans. ASABE 2015, 58, 1763-1785.

56. Yen, H.; White, M.J.; Jeong, J.; Arabi, M.; Arnold, J.G. Evaluation of alternative surface runoff accounting procedures using the SWAT model. Int. J. Agric. Biol. Eng. 2015, 8, 54-68.

57. Fox, J.F.; Davis, C.M.; Martin, D.K. Sediment source assessment in a lowland watershed using nitrogen stable isotopes. JAWRA J. Am. Water Res. Assoc. 2010, 46, 1192-1204. [CrossRef]

58. Mukundan, R.; Radcliffe, D.E.; Ritchie, J.C.; Risse, L.M.; McKinley, R.A. Sediment fingerprinting to determine the source of suspended sediment in a southern Piedmont stream. J. Environ. Qual. 2010, 39, 1328-1337. [CrossRef] [PubMed]

59. Wu, B.; Van Maren, D.; Li, L. Predictability of sediment transport in the Yellow River using selected transport formulas. Int. J. Sediment Res. 2008, 23, 283-298. [CrossRef]

60. United States Department of Agriculture-National Resources Conservation Service (USDA-NRCS). United States Department of Agriculture-National Resources Conservation Service (USDA-NRCS). Chapter 10: Estimation of direct runoff from storm rainfall. In Part 630: Hydrology: NRCS National Engineering Handbook; USDA National Resources Conservation Service: Washington, DC, USA, 2004.

61. Green, W.H.; Ampt, G.A. Studies on soil physics, part I, the flow of air and water through soils. J. Agric. Sci. 1911, 4, 1-24.

(C) 2017 by the authors; licensee MDPI, Basel, Switzerland. This article is an open access article distributed under the terms and conditions of the Creative Commons Attribution (CC BY) license (http:/ / creativecommons.org/licenses/by/4.0/). 